\title{
The genus Bilabrella Lindl. (Orchidaceae, Habenariinae): general characteristic and research history of the genus
}

\author{
Marta Kras* \& Dariusz L. Szlachetko
}

Department of Plant Taxonomy and Nature Conservation, the University of Gdańsk, Wita Stwosza 59, 80-308 Gdańsk, Poland

* corresponding author (e-mail: bgmk@univ.gda.pl)

\begin{abstract}
The genus Bilabrella (Habenarinae, Orchidaceae) was described by Lindley in 1834, but within next years, different authors incorporated it as the section of the genus Habenaria Willd. From 2003, Szlachetko and Kras stated that there were no grounds for distinguishing the sections Bilabrellae and Replicatae. They restored the genus Bilabrella, transfering to it 93 species from the section Replicatae and four species new to science were described. The poor condition of the old plant materials, the lack of some type specimens for many species described by Schlechter and problems with a series of transitional forms between some species are only few reasons, why the revision of the genus has not been published so far. Bilabrella comprises orchids found in Sub-Saharan Africa, Madagascar and neighbouring islands. Bilabrella differs from other Habenariinae in its unique combination of features.
\end{abstract}

Key words: taxonomy, research history, Orchidaceae, Habenaria, Bilabrella, Africa

\section{Introduction}

One of the most interesting representatives of the order Orchidales is the genus Habenaria Willd. It was described by the German botanist Willdenow in 1805 . Since that time, it has embraced terrestrial orchids, usually with inconspicuous green or white flowers. As exploration of tropical areas progressed more and more, new Habenaria species were described, considerably expanding the boundaries of the genus, and hence distorting its original definition. Not that long ago, Habenaria comprised about 600 species and the number of published names within it amounted to circa 2400 .

In 1901, Kraenzlin published the first revision of Habenaria in which he provided descriptions of the sections and species known to science at that time. Since then, many new species have been described and application of his Habenaria infrageneric classification often became impossible. Kraenzlin's revision turned out to be non-predictive and soon proved inadequate.
In 2000, Szlachetko and his team started to develop a taxonomic revision of Habenaria sensu latissimo. As a result of this work, the original Willdenowian definition of the genus was restored, the boundaries of Habenaria sensu stricto defined, the number of species contained within it limited and a range of new genera described (Szlachetko 2003a, 2003b, 2003c, 2003d; Szlachetko et al. 2003; Szlachetko \& Kras-Łapińska 2003; Szlachetko \& Sawicka 2003a, 2003b; Szlachetko 2004a, 2004b, 2004c, 2004d, 2004e, 2004f; Szlachetko \& Margońska 2004; Szlachetko 2005a, 2005b; Szlachetko \& Kras 2006a, 2006b, 2006c, 2006d, 2006e, 2006f). As a consequence of in-depth research of the collections maintained in Herbaria all over the world, and analysis of the original diagnoses, researchers have been able to enhance our knowledge of this plant group.

Unfortunately, conducting research on Habenaria encountered many difficulties, one of the most major was the destruction of Schlechter's Herbarium with its multiple type materials during the World War II. 
Bilabrella Lindl. is a taxon that is scarcely recognized, despite having been described nearly 180 years ago. So far, no revision of the genus has been published, so it is not known how many species it includes, which of those described should be distinguished and which should be regarded merely as synonyms. Its high infrageneric variability in relation to the structure of the perianth segments and the presence of series of species that are morphologically similar make Bilabrella a very interesting subject of study. Like any taxon whose systematic position is unclear, it does require taxonomic research.

The aim of the present work is to prepare a background to the taxonomic revision of Bilabrella. The first stage of the research involved determining the differences between Bilabrella and other African Habenariinae. The secondly, an infrageneric classification, the keys to determination and descriptions of all species are proposed.

\section{History of the research on Bilabrella Lindl.}

Within the order Orchidales, a dozen or so genera were described that comprise a considerable number of species. Until fairly recently, one of the larger taxa at the generic level was Habenaria Willd., which included about 2100-2450 species names (according to The International Plant Name Index 2013 and TropicosMissouri Botanical Garden database 2013). The genus was proposed by the German botanist, Willdenow, in the fourth edition of "Species Plantarum" published in 1805, where he included a description of two species, namely Habenaria brachyceratitis Willd. and Habenaria macroceratitis Willd. Willdenow did not indicate the type for the genus, which was standard procedure at that time. The quite brief description of the new genus caused serious taxonomic repercussions, as almost all species of terrestrial orchids which originated from tropical or subtropical areas and had white or greenish, usually inconspicuous, flowers started to be included in Habenaria. The confusion in the taxonomy of this group became even greater when Habenaria was made to include genera from the temperate zone of the northern hemisphere such as Platanthera Rich., Coeloglossum Lindl., Piperia Rydb. and some species of Orchis L., Gymnadenia R. Br. and Dactylorhiza Neck.

The genus Bilabrella was described by John Lindley in 1834. He placed there only one species, Bilabrella falcicornis (Edwards's Bot. Reg. 20: sub. t. 1701. 1834). In the generic description, Lindley regarded the following features as diagnostic: fleshy sepals; lateral sepals of medium size; leathery, relatively large petals; fleshy labellum with 3 lobes; the anther with elongated antherophores, which are free and directed forwards or upwards; the rostellum evenly linear-lanceolate, with fleshy, stalked rostellophores; petiolate leaves with narrow blade; elongate inflorescence. None of these features could differentiate Bilabrella from the broadly defined Habenaria. A few years later, Lindley himself subsumed his genus under Habenaria.

In the monograph "Beiträge zu einer Monographie der Gattung Habenaria Willd. (Allgemeiner Teil.)" in 1891, Kraenzlin proposed H. macroceratitis Willd. as type species for the genus. This, however, did not lead to defining unequivocal boundaries for the genus itself, nor for the section within it.

As a consequence, Rendle (1895), when describing a new species - Habenaria altior in "Flora of Eastern Tropical Africa" - included it in the section Bilabrellae, and a similar one, Habenaria ndiana in the section Replicatae. Rendle did not indicate the differences between these sections nor did he justify his view on this issue.

In 1901, another work by Kraenzlin was published which was only a revision of Habenaria, its title being "Orchidacearum Genera et Species". Among other things he mentioned 28 species there which he included in the section Replicatae. He stated that the differences between Replicatae and Bilabrella were so slight that these two should be treated as one. Kraenzlin defined the section Replicatae by the following features: labellum divided into three lobes, petals divided into two lobes; stigma with long stigmaphores.

In 1913, Bolus published "Orchids of Southern Africa". Knowing the defects of the Kraenzlin's study, and with no intention of revising the whole genus, the author listed the Habenaria species in an alphabetical order. Many researchers followed him.

Also in 1913, "Flora Capensis" was published, where there was a chapter on orchids written by Rolfe. He placed Habenaria, under the number XXIV, offering descriptions of 37 species. Following Bolus, he did not recognize sections. Based on the Kraenzlin's revision, Bilabrella should have included 9 species described by Rolfe.

One of the best known researchers of African orchids and discoverer of many of them was Summerhayes, who worked for the Royal Botanic Gardens at Kew. He described a great number of Habenaria species. In the early stages of his research on the genus, he accepted the existence of the separate sections Bilabrellae and Replicatae. This clearly results from the species descriptions in a series of his articles published in the Kew Bulletin entitled "African Orchids" (1931, 1932, 1942, 1960, 1962, 1966, 1968), in wich Habenaria limnophila Summerh. (1931) and Habenaria pauper (1932) were placed in the sections Replicatae and Bilabrellae, respectively. With time, Summerhayes 
acquired more experience in his study of Habenaria and accepted the Kraenzlin's proposal, uniting the two sections into one taxon. Each new taxon description by Summerhayes shows great care for detail. In 1968, two floras dealing with the western and eastern parts of tropical Africa were published by this author ("Flora of Tropical East Africa", "Flora of Tropical West Africa" ed. 2). Neither of them distinguished the section Bilabrellae and the Replicatae section was characterized as follows: anterior petal lobe longer than posterior lobe; both are narrow though, not always linear; spur almost straight or twisted; bract shorter than the combined length of ovary and pedicel. In "Flora of Tropical East Africa" (1968), Summerhayes pinpointed a phenomenon which had not been described by other researchers of this plant group. He noticed the relatively frequent presence of so-called abnormal forms or atypically formed flowers. In his opinion two species, Habenaria dactylostigma Kraenzl. and Habenaria inaequiloba Schltr., represent properly these forms. In Summerhayes' opinion, Habenaria simense, described by Henrich Gustav Reichenbach in 1849 (Linnaea 22: 859) represents an abnormal form of Habenaria antennifera, which had been described by Richard nine years earlier (Ann. Sci. Nat., Bot. 2(14): 268). Summerhayes placed information concerning this issue, among others, on the herbarium sheets of the plants he had been studying.

Williamson, in "Orchids of South Central Africa" (1977), offered quite brief descriptions of 17 species of the section Replicatae he had selected, and 5 unidentified species.

Geerinck (1984), when publishing Orchidaceae as a contribution to "Flore d'Afrique Centrale (Zaire-Rwanda-Burundi)", decided to omit the issue of the sections under dispute. He produced descriptions and analytical figures for some of the 15 species from Central Africa, which theoretically should have belonged to the section Replicatae.

In-depth research on Habenaria Willd. was conducted by la Croix and Cribb (1995). They noted 131 species of this genus in Mozambique, Malawi, Zimbabwe and Botswana. For each species they provided the type, precise quotation, list of synonyms, description, site location and ecological data. They included 34 species in the section Replicatae.

The results of analogous research conducted in Cameroon were published by Szlachetko and Olszewski in 1998. The list of species in the section Replicatae contained 25 taxa, 8 of them new to science.

In 2004, a volume was published by Szlachetko, Sawicka and Kras-Łapińska on Orchidaceae under the title "Flore du Gabon". The authors did not include a section Bilabrellae in Habenaria. Plants with lanceolate or linear leaves, small resupinate flowers, dorsal sepal reflexed, lateral sepals ending in an apiculus, petals divided into two basal lobes and gynostemium with outgrowths were all placed in the section Replicatae. The two species that occur in Gabon were Habenaria genuflexa Rendle and Habenaria schimperiana Hochst. ex A.Rich.

In 2003, as a result of the research conducted on herbarium material, as well as data from the literature, Szlachetko and Kras-Łapińska stated that there were no grounds for distinguishing the sections Bilabrellae and Replicatae. At the same time they restored the genus Bilabrella, transfering to it 60 species from the section Replicatae. In the course of further investigation, the authors changed the genus classification of other 11 species (Szlachetko \& Kras 2006f).

While analysing the materials collected for the present paper, other 22 taxa were transferred to Bilabrella (Kras \& Szlachetko 2009). Four species new to science were described (Kras \& Szlachetko 2008) and, as a result, the genus now contains 97 species.

The taxonomic research on Bilabrella encountered many problems. First of all, many of the species presently included in this genus were described in the $19^{\text {th }}$ century based on fragments of their inflorescences or single flowers. The condition in which they are found today often makes meaningful microscopic examination of them difficult or impossible. An extreme case is that of Habenaria anaphysema Rchb.f., whose type material takes the form of a drawing on a herbarium sheet. The type materials for many species described by Schlechter (e.g. 1906, 1915) got burnt in Berlin during the World War II. The location or existence of the isotypes for many of Schlechter's taxa, e.g. Habenaria barbarae Schltr., are not known. In many cases, the species descriptions published by their authors turn out to be far from useful as they are often very brief and enigmatic. The diagnosis of Habenaria incarnata consists of one sentence only.

Another problem is a series of transitional forms between some species of the genus. The differentiation between the type materials is usually unproblematic, but the labelling of other materials may raise certain doubts. This seems to result from the rapidly developing speciation within, not only Bilabrella but more widely, in the majority of the Habenariinae, and, thus, from the ease of hybrid creation and/or a high infrageneric variability.

Research on the ecological requirements of Bilabrella might answer the question as to whether the infrageneric variability observed is a result of adaptation to a different habitat or is genetic in nature. As a matter of fact, light exposure may considerably affect the size of a plant or its elements. Unfortunately, the orchids of this genus have not been the subject to any ecological studies. 


\section{Characteristics of the genus Bilabrella Lindl.}

\subsection{Systematic position}

In 1995, Szlachetko placed 13 genera in the subtribe Habenariinae: Ala Szlach., Arnottia A.Rich., Bonatea Willd., Centrostigma Schltr., Cynorkis Thouars, Diplomeris D.Don, Habenaria Willd., Kryptostoma (Summerh.) Geerinck, Megalorchis H.Perrier, Physoceras Schltr., Platycoryne Rchb.f., Roeperocharis Rchb.f., ?Tsaiorchis Tang. \& Wang. As a result of the research conducted by Szlachetko and his team since 2000 further genera have been excluded from Habenaria sensu latissimo, but they still belong to the Habenariinae which currently contains 42 members.

Order: Orchidales Bromhaed

Family: Orchidaceae Juss.

Subfamily: Orchidoideae

Tribe: Orchideae

Subtribe: Habenariinae Benth. Ala Szlach.
Alinorchis Szlach.

Arachnaria Szlach.

Arnottia A. Rich.

Ate Lindl.

Bertauxia Szlach.

Bicornella Lindl.

Bilabrella Lindl.

Bonatea Willd.

Centrostigma Schltr.

Ceratopetalorchis Szlach., Górn. \& Tuk.

Cynorkis Thouars

Diplomeris D. Don

Fimbrorchis Szlach.

Habenaria Willd.

Habenella Small

Kraenzlinorchis Szlach.

Kryptostoma (Summerh.) Geerinck Kusibabella Szlach.

Lowiorchis Szlach.

Macrura Szlach. \& Sawicka

Medusorchis Szlach.

Megalorchis H. Perr.
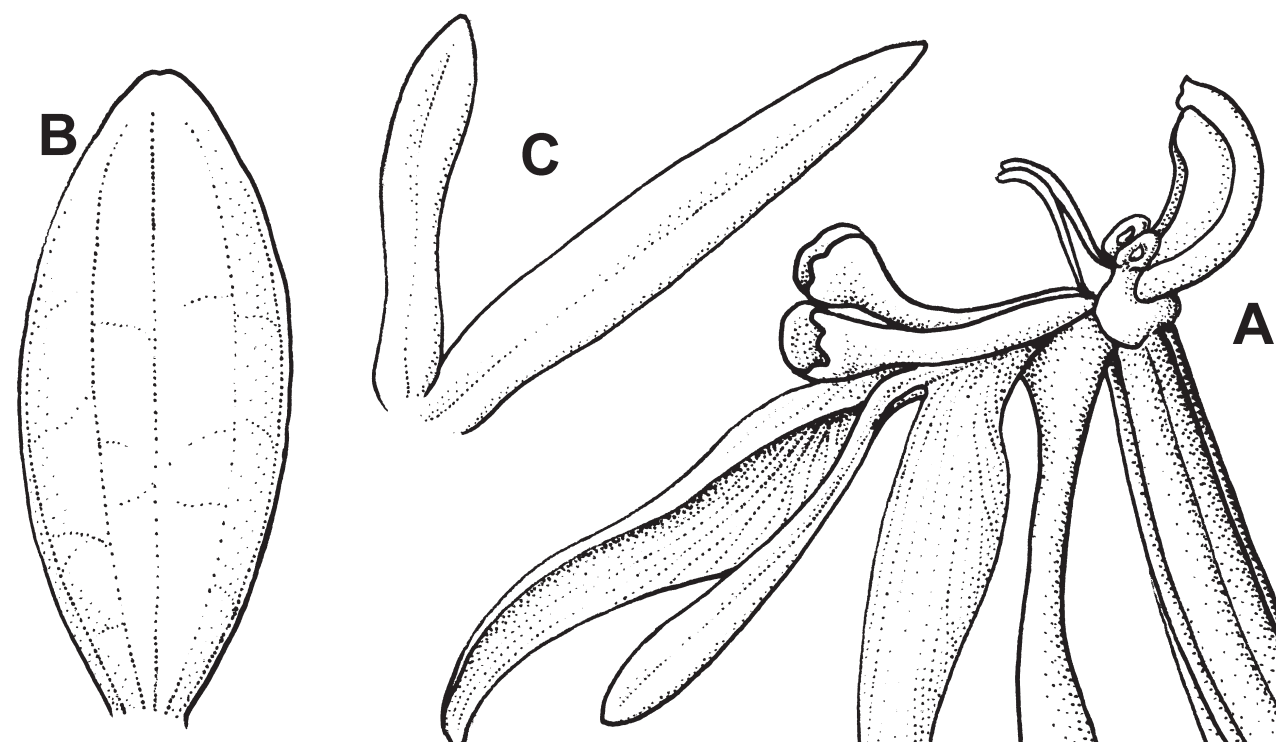

HBM
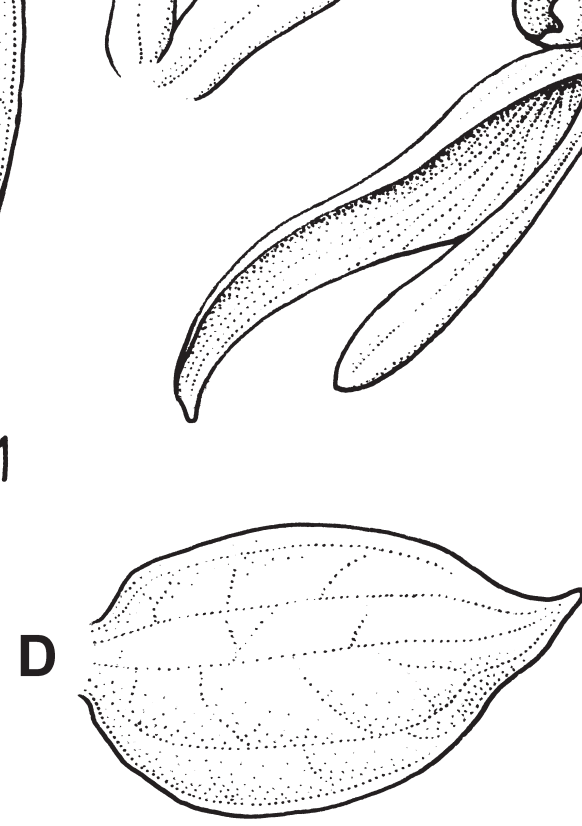

Fig. 1. Mirandorchis calvilabris (Summerh.) Szlach. \& Kras.-Lap.

Explanations: A - gynostemium, lip, spur and ovary, B - dorsal sepal, C - divided petal, D - lateral sepal (drawn by H. B. Margońska) 
Mirandorchis Szlach. \& Kras-Lap.

Monadeniorchis Szlach. \& Kras

Montolivaea Rchb.f.

Ochyrorchis Szlach.

Physoceras Schltr.

Plantaginorchis Szlach.

Platycoryne Rchb.f.

Platycorynoides Szlach.

Podandriella Szlach.

Pseudocoeloglossum Szlach.

Pseudohemipilia Szlach.

Renzorchis Szlach. \& Olszewski

Roeperocharis Rchb.f.

Schlechterorchis Szlach.

Senghasiella Szlach.

Smithanthe Szlach. \& Marg.

Trachypetalum Szlach. \& Sawicka

Tsaiorchis Tang \& F. T. Wang.

Veyretella Szlach. \& Olszewski
Bilabrella Lindl. seems to be related to a few other genera which have also been excluded from Habenaria sensu lattisimo.

Mirandorchis is a genus that appears to be very close to Bilabrella in terms of its habit. Mirandorchis was described by Szlachetko and Kras-Łapińska in 2003 (Fig. 1). The differences between the two genera may be observed when comparing the morphology of the lateral sepals. In Mirandorchis, their apiculi are not prominent. Mirandorchis resembles Bonatea Willd. in its gynostemium structure. The pollen sacs are large and joined to a relatively narrow connective which protrudes over them. The central rostellum lobe is also large and subulate, while the stigmaphores are massive and wide in comparison with those in Bilabrella.

Many more differences can be found when comparing Bilabrella and Renzorchis Szlach. \& Olszewski (1998). Representatives of the latter are characterized


Fig. 2. Renzorchis pseudoplatycoryne Szlach. \& Olsz.

Explanations: A - spur, ovary, and pedicel, B - dorsal sepal, C - divided petal, D - lateral sepal, E - lip (drawn by A. Król) 

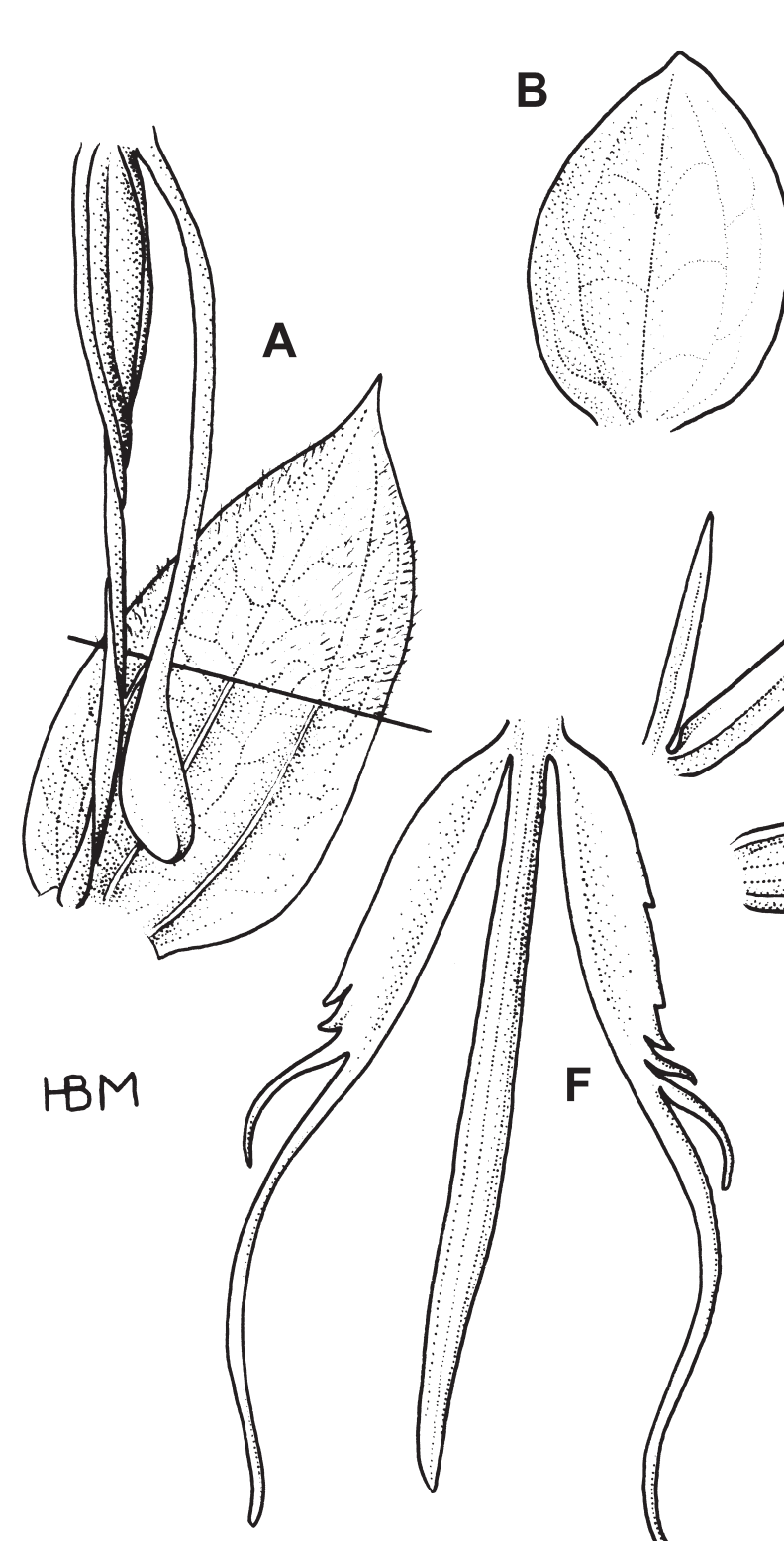

( )

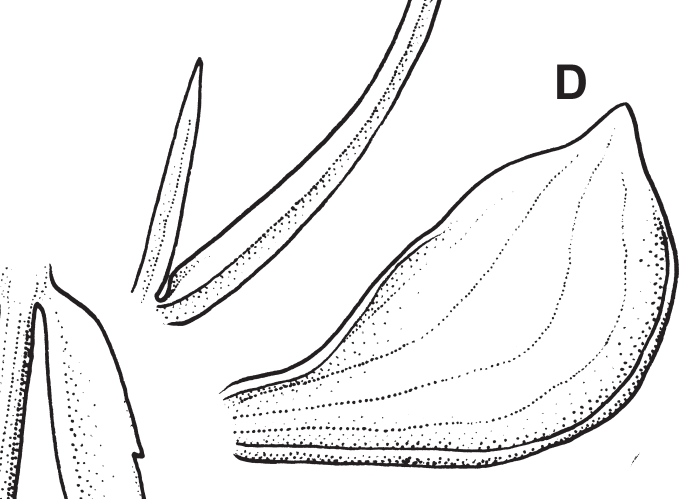

Fig. 3. Ceratopetalorchis sanfordiana (Szlach. \& Olsz.) Szlach., Górniak \& Tukałło

Explanations: A - spur, ovary, pedicel and bract, B - dorsal sepal, C - divided petal, D - lateral sepal, E - lateral sepal in natural position, F - lip (drawn by H. B. Margońska)

by the special structure of their gynostemium - the viscidia are produced in the mid-way of the lateral rostellum lobes, a feature not found in any other members of the Habenariinae. The two genera are very similar to each other in habit and structure of their floral parts (Fig. 2).

In 2003 Szlachetko, Górniak and Tukałło raised the section Ceratopetalae Kraenzl. to generic rank, giving it a new name: Ceratopetalorchis (Fig. 3). The generative structure is almost identical to that found in Bilabrella. The shape of the perianth elements, however, is different. The representatives of Ceratopetalorchis species are characterized by the lanceolate, frequently divided lateral lobes of the labellum; the posterior lobes of the petals are very long and intertwined above the helmet formed by the dorsal sepal and the anterior lobes of the petals, giving these flowers a unique appearance. Vegetatively Ceratopetalorchis differs from Bilabrella in its leaves, which are always lanceolate and borne throughout the stem.

Another genus that is closely related to Bilabrella is Platycorynoides, described by Szlachetko in 2005 (2005a) (Fig. 4). The similarities between the representatives of these taxa may be noticed in the structure of their vegetative and floral parts. Their generative structures, on the other hand, are totally different. The 




Fig. 4. Platycorynoides hircina (Rchb. f.) Szlach.

Explanations: A - habit, B - flower, C - lip, D - gynostemium, side view, E - gynostemium, front view (drawn by H. B. Margońska)

labellum in Platycorynoides is also 3-lobed, but its lateral lobes are short and linear. The gynostemium is very similar to that of Platycoryne Rchb.f. (short, massive, oval-conical) and differs greatly from that found in Bilabrella species.

\subsection{Morphological structure}

Bilabrella Lindl. differs from other Habenariinae in its unique set of features. The most important diagnostic characters include the strongly asymmetric and reflexed lateral sepals, pointed with an apiculus; petals divided into two lobes almost to the base; the deeply 3-lobed lip of usually filamentous or linear segments and the gynostemium structure (Fig. 5).
The tuber is single, ovoid to ellipsoid, with diameter from $1 \mathrm{~cm}$ [e.g. Bilabrella hebes (la Croix \& P. J. Cribb) Szlach. \& Kras-Lap.] to $2.5 \mathrm{~cm}$ [Bilabrella falcicornis Lindl.]. Its length ranges from $1.2 \mathrm{~cm}$ to $2.2 \mathrm{~cm}$ in $B i$ labrella hochstetteriana (Kraenzl. \& Schltr.) Szlach. \& Kras (Lindley gives a length of $5 \mathrm{~cm}$ for this species). The roots are thin and short $-10 \mathrm{~cm}$ long and about $1 \mathrm{~mm}$ in diameter.

The tuber produces a single upright stem, always glabrous and terminating in an inflorescence. The height varies from a $12 \mathrm{~cm}$ in Bilabrella subaequalis (Summerh.) Szlach. \& Kras-Lap. (Summerhayes 1962) to about $100 \mathrm{~cm}$ in Bilabrella schimperiana (Hochst. ex A. Rich.) Szlach. \& Kras-Lap. Exceptionally it can even 


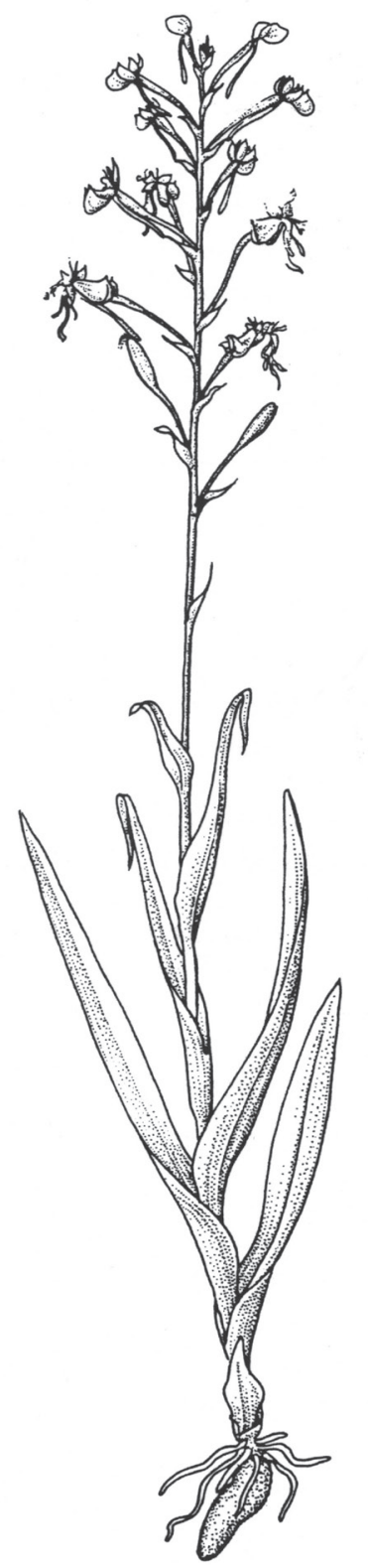

Fig. 5. Bilabrella Lindl. habit exemplified by Bilabrella macrotidion (Summerh.) Szlach. \& Kras.-Lap. (ex La Croix \& Cribb in Pope, 1995)

reach $200 \mathrm{~cm}$, as in a specimen of Bilabrella sochensis (Rchb.f.) Szlach. \& Kras-Lap. recorded by La Croix \& Cribb (1995).

The leaves are usually confined to the lower $1 / 3-1 / 4$ of the stem. They gradually decrease in size upwards, providing a smooth transition upper leaves, and then the bracts. Leaves may be widely spaced or overlapping at the base, appressed or strongly patent. The lower 3 to 6 leaves tend to be linear or lanceolate, acute, sessile, sheathed and nonglandular. The upper leaves are of the same form or wider then the lower ones and may be glabrous, as in Bilabrella chirensis (Rchb.f.) Szlach. \& Kras-Lap., or glandular as in Bilabrella kyimbilae (Schltr.) Szlach. \& Kras-Lap. Some of them have a characteristic reddish veins, as e.g. in Bilabrella hochstetteriana (Kraenzl. \& Schltr.) Szlach. \& Kras.

The inflorescence varies in length from $4 \mathrm{~cm}$ in Bilabrella cribbiana (Szlach. \& Olszewski) Szlach. \& Kras-Lap. (Szlachetko \& Olszewski 1998) up to $30 \mathrm{~cm}$ or more as in Bilabrella disparilis (Summerh.) Szlach. \& Kras-Lap. $(27.1 \mathrm{~cm})$ or Bilabrella schimperiana (Hochst. ex A.Rich.) Szlach. \& Kras-Lap. (31,5 cm). It may be dense [Bilabrella dives (Rchb.f.) Szlach. \& Kras] or lax [Bilabrella scimperiana (Hochst. ex A.Rich.) Szlach. \& Kras-Lap.] The number of flowers usually ranges from 10 [Bilabrella macrostele (Summerh.) Szlach. \& Kras-Lap.] to 25, with some species such as Bilabrella weberana (Schltr.) Szlach. \& Kras-Lap. having 33 flowers and Bilabrella marxiana (Schltr.) Szlach. \& Kras as many as 50.

The flowers are usually green, white or yellowish, small, rather inconspicuous, always resupinate through $180^{\circ}$. On the surface of the ovary and peduncle there are six clearly marked ribs that correspond to the accretion sites and carpel bundles. These ribs are sometimes corrugated. The ovary in Bilabrella galpini (Bolus) Szlach. $\&$ Kras-Lap. is glandular. The peduncle varies in length from $5 \mathrm{~mm}$ in Bilabrella anaphysema (Rchb.f.) Szlach. \& Kras-Lap. to $17 \mathrm{~mm}$ in Bilabrella huillensis (Rchb.f.) Szlach. \& Kras-Lap. Each flower is subtended by a bract which may tightly enfold the peduncle or loosely surround it. The bract may reach half the length or enclose it completely. In most species bracts are glandular; however, they can be glandular throughout [Bilabrella marxiana (Schltr.) Szlach. \& Kras], or just up to half their length [Bilabrella tubifolia (La Croix \& P. J. Cribb) Szlach. \& Kras-Lap.] (Fig. 6A).

The dorsal sepal is usually folded or sunk about the central nerve, creating a shell-like appearance (Fig. 6B). It may cover a part of the gynostemium or even take up a position so that it lies on the upper surface of the ovary. Unlike many Habenariinae, it never forms a helmet (a so-called galea) with the petals' posterior lobes; they only lie in close proximity to one another. The mean dimensions of the dorsal sepal are $5 \mathrm{~mm}$ by $2 \mathrm{~mm}$. The smallest dorsal sepal was recorded in Bilabrella pedicellaris (Rchb.f.) Szlach. \& Kras (4 mm by 1.2 $\mathrm{mm}$ ), and the largest in Bilabrella kyimbilae (Schltr.) Szlach. \& Kras-Lap. ( $6 \mathrm{~mm}$ by $3 \mathrm{~mm}$ ).

The lateral sepals are much larger than the dorsal one; they are strongly asymmetric, apiculate, reflexed and are appressed to the ovary. Their shape varies little across all species of the genus. Their margins are often involute. Sepal length ranges from 5 to $8.6 \mathrm{~mm}$ and width from 3 to $6 \mathrm{~mm}$. The apiculus may be up to 0.5 $\mathrm{mm}$ long. The lateral sepals are usually 5-nerved (Fig. 6D) and glabrous, except for Bilabrella macrostele (Summerh.) Szlach. \& Kras-Lap. where they are glandular on their outer surface (like the dorsal sepal). 


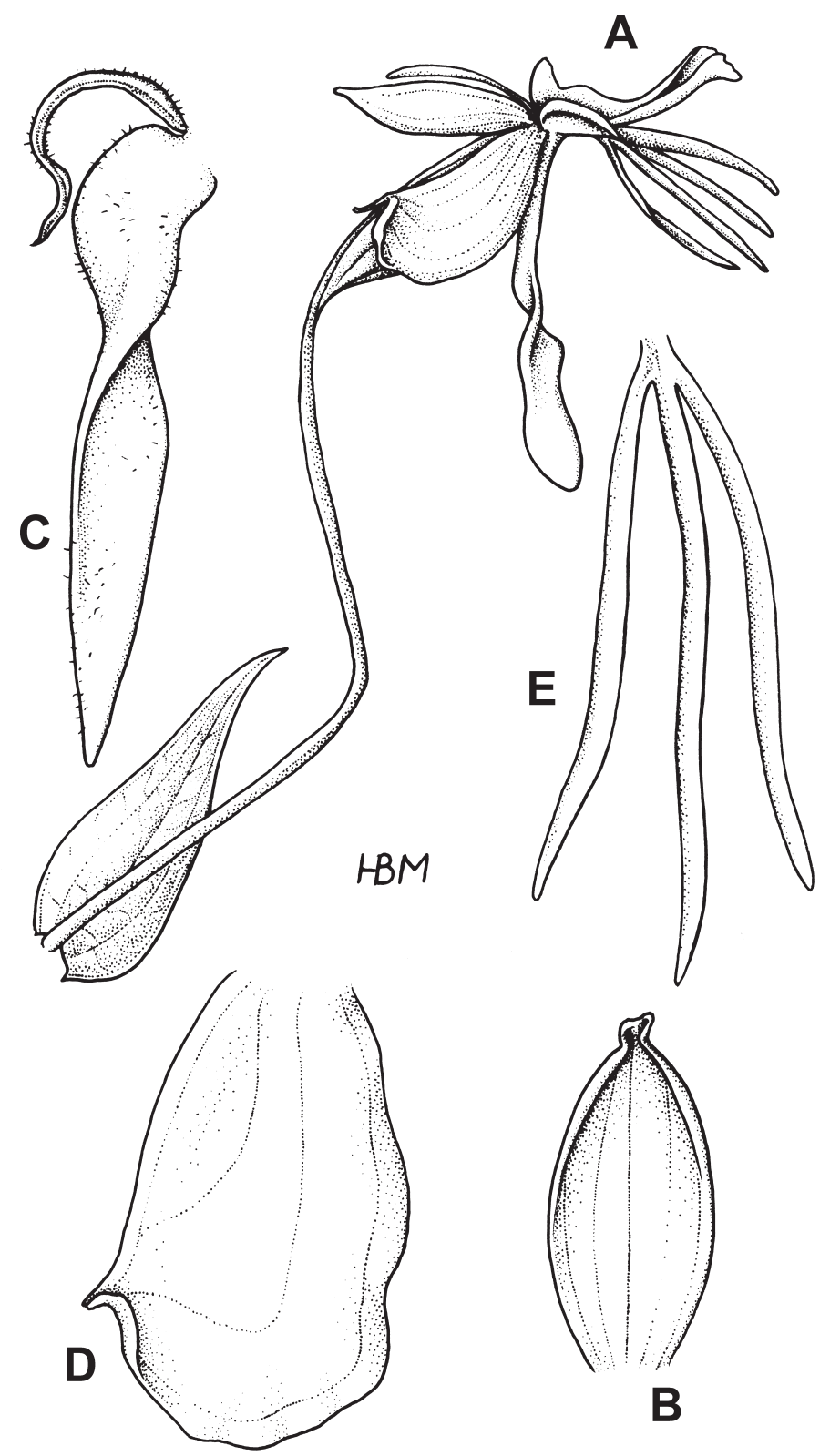

Fig. 6. Flower structure of the genus Bilabrella Lindl. exemplified by Bilabrella schimperiana (Hochst. ex A. Rich.) Szlach. \& Kras-Lap. Explanations: A - flower, B - dorsal sepal, C - divided petal, D - lateral sepal, E - lip (drawn by H. B. Margońska)

The petals are divided into two lobes, posterior and anterior, which differ in size or shape (Fig. 6C). They may fork at the base or be partly connate (up to $0.5 \mathrm{~mm}$ ) as in Bilabrella humilior (Rchb.f.) Szlach. \& Kras-Lap.

The posterior petal lobe, along with the dorsal sepal, may cover the gynostemium or bend upwards, or deviate to the back for half its length. It is linear, mostly measuring ca. $4 \mathrm{~mm}$ by $0.3 \mathrm{~mm}$ and is frequently 3 -nerved. In Bilabrella myodes (Summerh.) Szlach \& Kras-Lap. the posterior lobe is much larger (15 $\mathrm{mm}$ by $1.1 \mathrm{~mm})$. In many species it is glabrous but in some it is glandular, ciliate or ciliolate all over the surface (e.g. Bilabrella anaphysema (Rchb.f.) Szlach. \& Kras-Lap.) or at the base only (e.g. Bilabrella macrostele (Summerh.) Szlach. \& Kras-Lap.).
The anterior petal lobe deviate to the back and down or lies along the gynostemium outgrowths. It is usually much larger than the posterior lobe, linear or lanceolate, often very fleshy and unnerved. It is usually between 6.5 and $15 \mathrm{~mm}$ long and from 1 to $2 \mathrm{~mm}$ wide. Like the posterior lobe, it may be glabrous, glandular all over, or only in the lower half.

Of course, there are exceptions. Thus, Bilabrella kilimanjari (Rchb.f.) Szlach. \& Kras-Lap. possesses petals which are more or less lobular shape, the posterior lobe measuring $5.5 \mathrm{~mm} \times 1.5 \mathrm{~mm}$, and the anterior $4 \mathrm{~mm} \times 2 \mathrm{~mm}$.

The lip always consists of three lobes (Fig. 6E). They may be free to the base [Bilabrella cataphysema (Rchb.f.) Szlach. \& Kras-Lap.], or connate at the base for $0.5 \mathrm{~mm}$ [Bilabrella humbertii (Szlach. \& Olszewski) 

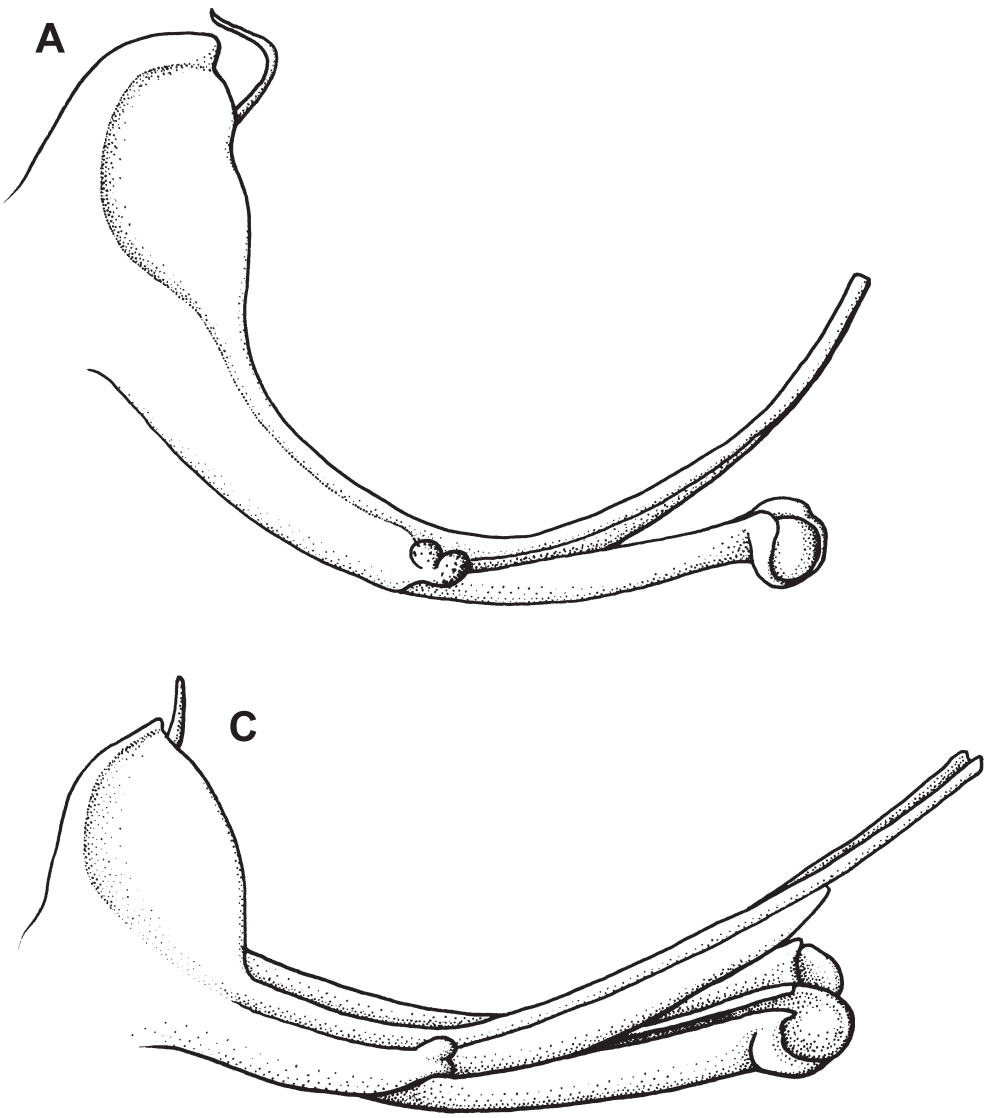

Fig. 7. Generative structure of the genus Bilabrella Lindl. exemplified by Bilabrella schimperiana (Hochst. ex A. Rich.) Szlach. \& Kras-Lap. (A, B) and B. genuflexa (Rendle) Szlach. \& Kras-Lap. (C, D)

Explanations: A, C - side view, B, D - front view (drawn by H. B. Margońska)

Szlach. \& Kras-Lap.] or united for $2.5 \mathrm{~mm}$ [Bilabrella pedicellaris (Rchb.f.) Szlach. \& Kras]. All the labellum parts are arranged parallel to one another and hang free, upturned at the tip, with the lateral lobes curved outwards. All lobes are either similar in shape, linear, or the central one is linear and the lateral ones lanceolate as in Bilabrella incarnata (Lyall ex Lindl.) Szlach. \& Kras-Lap. All lobes are three-nerved and usually glabrous. In Bilabrella arianae (Geerinck) Szlach. \& Kras, the whole labellum is covered in papillae of various lengths, while in $B$. williamsonii it is finely glandular. In Bilabrella marxiana (Schltr.) Szlach. \& Kras the central lobe is fleshy and folded along the central nerve.

All Bilabrella Lindl. flowers possess a spur whose shape and size are diagnostically important at species level. It may be short and adjacent to the ovary [Bilabrella chirensis (Rchb.f.) Szlach. \& Kras-Lap.], or long and curved [Bilabrella burttii (Summerh.) Szlach. \& Kras-Lap.], or hang down freely. The bract may enfold it tightly, along with the pedicel and ovary. Usually the spur is cylindrical, often swollen or ampullaceous at the top [Bilabrella cataphysema (Rchb.f.) Szlach. \& Kras-Lap.] and may be twisted.

The gynostemium varies from delicate to relatively massive (Fig. 7). The anther is straight, ovoid to ellipsoid.
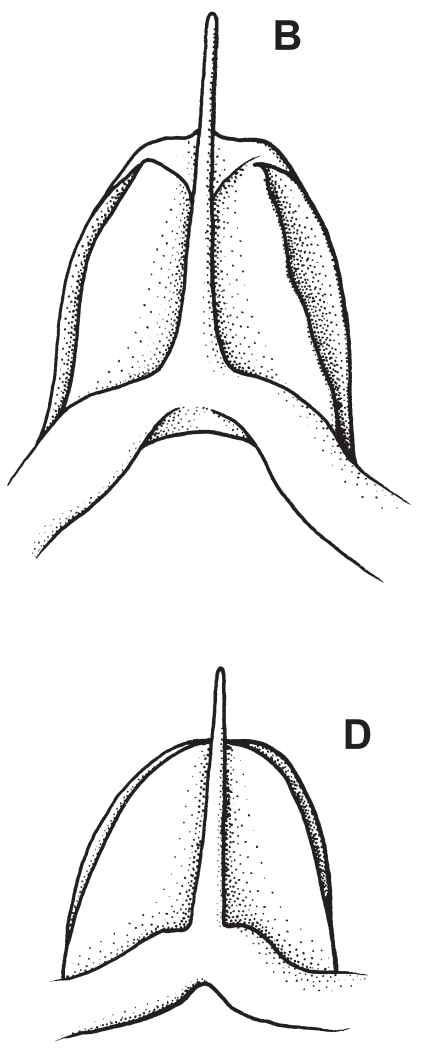

The generative features that distinguish Bilabrella from other Habenariinae and give them a unique appearance are their antherophores, stigmaphores, and rostellophores. Of these the stigmaphores are usually longer than the others. All of them tend to be very thin, delicate, and may be glabrous, or partly glandular as in Bilabrella hebes (la Croix \& P. J. Cribb) Szlach. \& Kras-Lap. In Bilabrella involuta (Bolus) Szlach. \& Kras they are up to $5 \mathrm{~mm}$ long and 0.3 to $0.5 \mathrm{~mm}$ wide. The rostellum median lobe is acute at the apex and may extend out over the connective as in Bilabrella schimperiana (Hochst. ex A.Rich.) Szlach. \& Kras-Lap., or be fully covered by the pollen sacs [Bilabrella myodes (Summerh.) Szlach. \& Kras-Lap.].

The connective is relatively narrow. The pollinia are from obovoid to ellipsoid, usually shorter than the very thin caudicules. The auriculae are small [Bilabrella burtii (Summerh.) Szlach. \& Kras-Lap. - 0.4 x $0.1 \mathrm{~mm}]$, or relatively large [Bilabrella tetrapetaloides (Schltr.) Szlach. \& Kras $-0.5 \times 0.9 \mathrm{~mm}$ ], digitate and sculptured. They may be divided throughout their length [Bilabrella incarnata (Lyall ex Lindl.) Szlach. \& Kras-Lap.] or just at the tip [Bilabrella tubifolia (la Croix \& P. J.Cribb) Szlach. \& Kras-Lap.]. Undivided auriculae can be observed in e.g. Bilabrella falcata (G.Will.) Szlach. \& Kras-Lap. and Bilabrella robusta (Welw.) Szlach. \& Kras-Lap. 


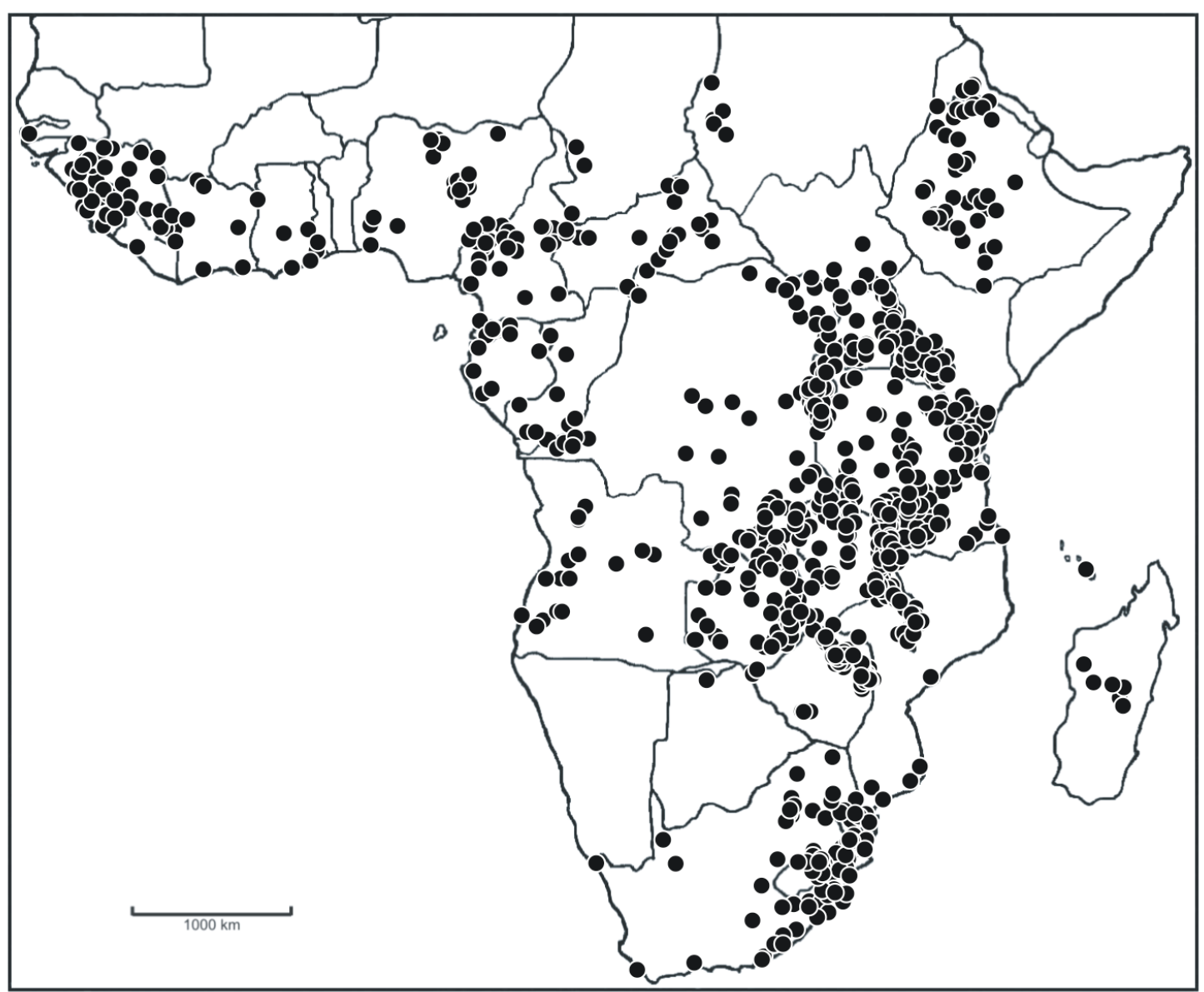

Fig. 8. Distribution map of orchids from the genus Bilabrella Lindl. Explanation: $\bullet-$ occurence of representatives of the species

An exceptional generative structure for the genus is found in Bilabrella dives (Rchb.f.) Szlach. \& Kras, Bilabrella macrostele (Summerh.) Szlach. \& Kras-Lap. and Bilabrella orangana (Rchb.f.) Szlach. \& Kras where the antherophores, stigmaphores and rostellophores are relatively short.
The fruit is usually ellipsoid, more or less curved and generally tinted brown.

\subsection{Geographical distribution}

Bilabrella comprises species found in Sub-Saharan Africa, Madagascar and neighbouring islands (Fig. 8).

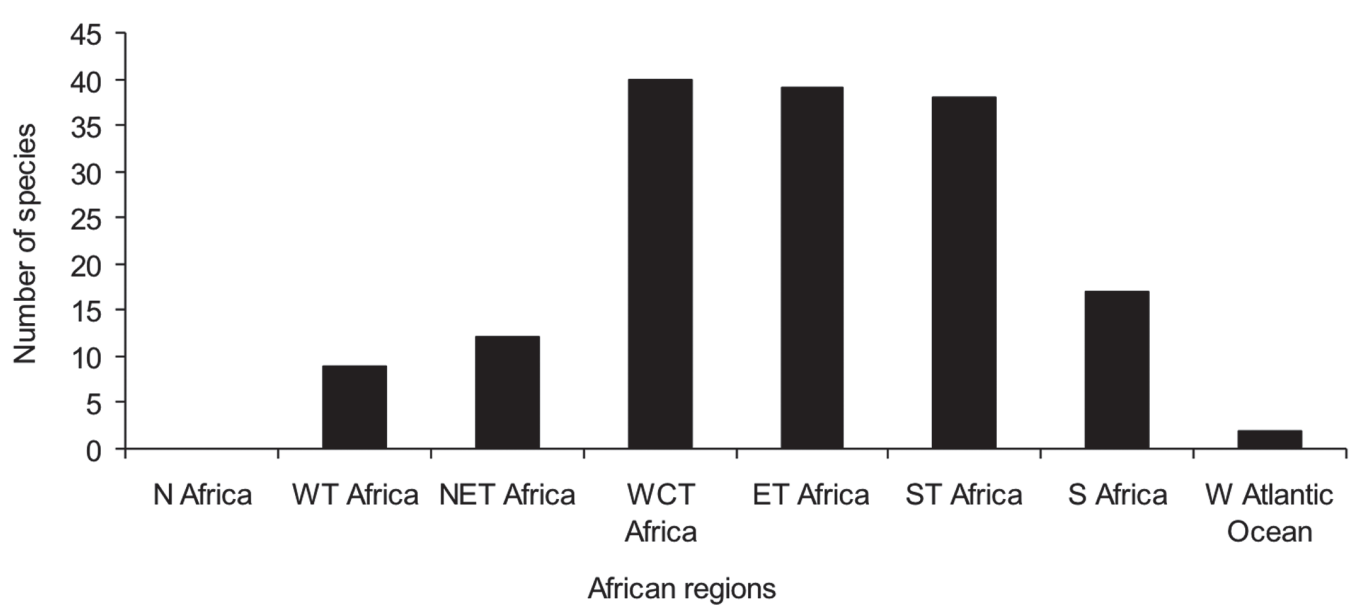

Fig. 9. Occurrence of Bilabrella Lindl. species in Africa's regions

Explanations: N Africa - North Africa, WT Africa - West Tropical Africa, NET Africa - North-East Tropical Africa, WCT Africa - West-Central Tropical Africa, ET Africa - East Tropical Africa, ST Africa - Southern Tropical Africa, S Africa - South Africa, W Atlantic Ocean - West Indian Ocean 


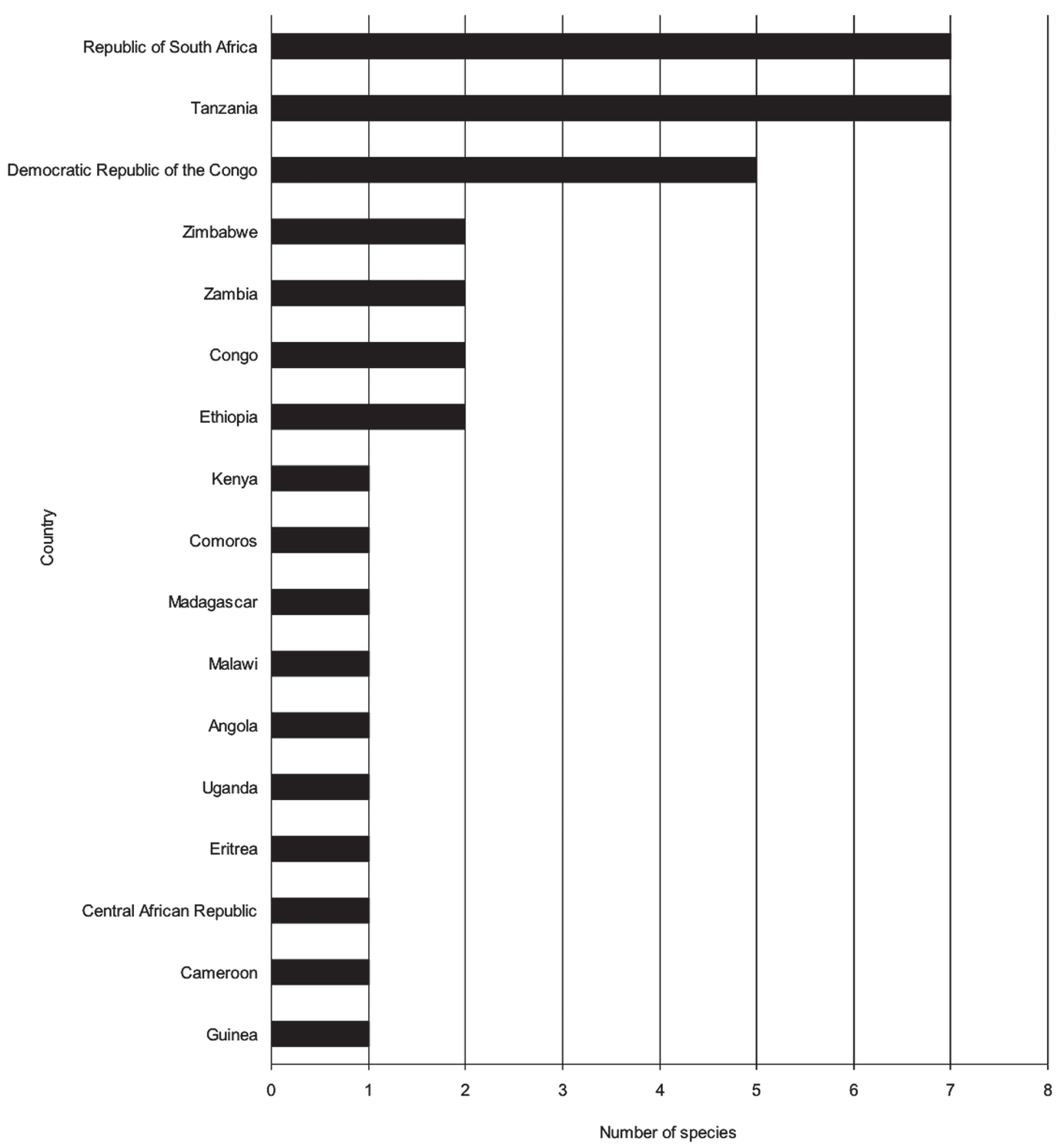

Fig. 10. Number of endemics recorded in African countries

West-East they extend right across the continent from the Atlantic to the Indian Oceans. To the north they reach Senegal and southern Chad and in the south, extend right down to Cape Province. They have not been recorded in the Namib Desert, while Bilabrella retinervis (Summerh.) Szlach. \& Kras-Lap. is the only species of the genus to have been found in the Kalahari Desert.

Out of 97 species in the genus, 16 have a wide distribution that covers a considerable part of the continent (three or more regions in Africa's geobotanical division by Brummit 2001). For example, Bilabrella ichneumonea (Sw.) Szlach. \& Kras-Lap., one of the species with the widest range of occurrence, is known in 5 geobotanical regions (21 states).

The area that is richest in Bilabrella species is Tropical East Africa where as many as 36 species have been found $(39 \%$ of the total number of taxa at this rank). Next come Tropical West-Central Africa and Tropical Southern Africa (both with 35 species). The plant cover in these areas is mainly savanna, a habitat preferred by most Bilabrella species (Fig. 9).

The state richest in endemics is probably Tanzania, although only one of the seven recorded there was initially so defined. There are probably 7 in the Republic of South Africa but confirmation requires further research. In the Democratic Republic of Congo the endemics Bilabrella bertauxiana (Szlach. \& Olszewski) Szlach. \& Kras-Lap., Bilabrella humbertii (Szlach. \& Olszewski) Szlach. \& Kras-Lap., Bilabrella renziana (Szlach. \& Olszewski) Szlach. \& Kras-Lap., Bilabrella stanislawii Szlach. \& Kras and Bilabrella tangheana (Geerinck \& Schaijes) Szlach. \& Kras are found. These species were described in the 1990s and are known only from the type specimens. Two endemics have been collected in each of the Ethiopia, Congo, Zambia and Zimbabwe and one in Angola, Cameroon, Central African Republic, Comoros, Eritrea, Guinea, Kenya, Madagascar, Malawi and Uganda (Fig. 10). 


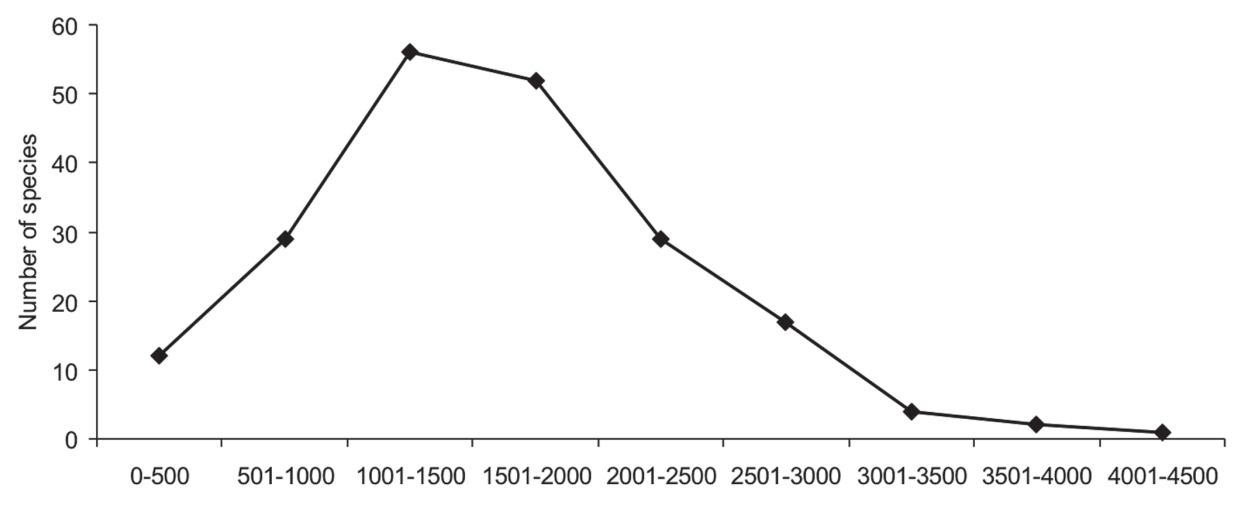

Fig. 11. Altitudinal distribution of Bilabrella Lindl.

Africa is an upland continent, with valleys traversing its numerous plateaux. About $70 \%$ of the land area lies between 300 and 2000 metres above sea level, and the mean height of the continent is $660 \mathrm{~m}$ (Podbielkowski 1987). The lowest land is coastal or borders rivers. Where it is covered in dense wet forest and mangrove swamp. These habitats are not favoured by Bilabrella, so few species grow below $500 \mathrm{~m}$. Only 13 species in total have been recorded including Bilabrella plectomaniaca (Rchb.f. \& S. Moore) Szlach. \& Kras-Lap. found at a height between 30 and $420 \mathrm{~m}$ in South Africa and Bilabrella tetrapetala (Rchb.f.) Szlach. \& Kras discovered at $100 \mathrm{~m}$.

The majority of species grow between 500 and $2000 \mathrm{~m}$. At the optimum height of ca. $1000 \mathrm{~m} 53$ species occur, way beyond the average height of the continent. The high-mountain species include e.g. Bilabrella altior (Rendle) Szlach. \& Kras-Lap., found on the slopes of Kilimanjaro in Tanzania at $3300 \mathrm{~m}$, and Bilabrella ichneumonea (Sw.) Szlach. \& Kras-Lap. collected at $3800 \mathrm{~m}$ in Angola (Fig. 11).

A sizable group of Bilabrella spp. tolerate a wide altitudinal range, e.g. Bilabrella welwitschii (Rchb.f.) Szlach. \& Kras-Lap. grows from sea level up to 2700 m. Specimens of Bilabrella anaphysema (Rchb.f.) Szlach. \& Kras-Lap. were found at sea level in Ghana (Gold Coast), as well as at $4200 \mathrm{~m}$ in Zambia.

Analysis of the material collected suggests that 34 Bilabrella species are confined to a very narrow altitudinal band, e.g. Bilabrella strangulans (Summerh.) Szlach. \& Kras-Lap. grows in open forest between 1200 and $1300 \mathrm{~m}$. No information has been collected on the altitudinal distribution of 15 Bilabrella species.

\subsection{Ecology}

Information on the ecological requirements of Bilabrella is usually sketchy. It is gleaned from collector' notes on herbarium labels or from incidental observations in the field. The genus has not been subject to detailed ecological research so far.
Bilabrella is a terrestrial orchid that prefers the lateritic soils associated with savannas, loams and red soils. Bilabrella schimperiana (Hochst. ex A. Rich.) Szlach. \& Kras-Lap. grows on hydromorphic, organically rich loams. A small group of the species are lithophytes appearing on the thin layers of the soil that develop between rocks, e.g. Bilabrella tortilis (P. J. Cribb) Szlach. \& Kras-Lap. They are also to be seen on granitie substrates and volcanic soils.

Based on data obtained from herbarium labels it may be concluded that the majority of Bilabrella species are heliophytes. Thus most species were recorded in open areas - savannas [Bilabrella urundiensis (Summerh.) Szlach. \& Kras], meadows and marshes of various kinds [Bilabrella thomsonii (Rchb.f.) Szlach. \& KrasLap.]. Relatively often they were found also in dambos; Brachystegia spp. bushwood (Miombo forests), Uapaca spp. bushwood [Bilabrella tubifolia (la Croix \& P. J. Cribb) Szlach. \& Kras-Lap.] or of Acacia spp. [Bilabrella vollesenii (Thomas \& P. J. Cribb) Szlach. $\&$ Kras-Lap.]. They are rarely seen on forest fringes or steppes [Bilabrella macrostele (Summerh.) Szlach. $\&$ Kras-Lap.]. Some species occur quite commonly in Eucalyptus plantations such as Bilabrella galpini (Bolus) Szlach. \& Kras-Lap., or under pines [Bilabrella sochensis (Rchb.f.) Szlach. \& Kras-Lap.].

Some species, e.g. Bilabrella ichneumonea (Sw.) Szlach. \& Kras-Lap., are hydrophytes and grow in still, shallow water.

Based on the somewhat selective information it is difficult to infer the phenology of these plants. Flowering usually extends over a few months. Specimens of one species were found in flower at different times of the year - flowering may be initiated by a drop in temperature for a few days or rain. Flowering specimens of some species were have only been recorded within a single month, e.g. specimens of Bilabrella furcipetala (Schltr.) Szlach. \& Kras have been collected only in April. 
Flowers develop gradually, starting from the base of the inflorescence, so that a single specimen sometimes has developing fruit open at the base, flowers attractive to pollinators in the middle and unopened buds at the top of the inflorescence. After seeding, the above-ground parts of the plant die. The underground tubers remain dormant for a few months and then, in the rainy season, produce stems again (Stewart \& Campbell 1996). Therefore the life cycle of these plants resembles that of other species of the subtribes Habenariinae and Orchidinae.

Bilabrella species are insect pollinated. There have been no direct observations of the pollination of these plants, yet based on the arrangement of the inflorescence, flower structure and colour, it may be inferred that pollen is mainly transferred by night butterflies. The fragrance of the flowers is most noticeable during the evening and night when these insects are active. An unpleasant, sweet and nauseating smell has been observed in Bilabrella chirensis (Rchb.f.) Szlach. \& Kras-Lap. and Bilabrella schimperiana (Hochst. ex A. Rich) Szlach. \& Kras-Lap. Sometimes the flowers have a very strong smell as in Bilabrella myodes (Summerh.) Szlach. \& Kras-Lap.

Adaptation to night butterflies pollination is evident from the structure of the individual parts of the flower: the long pointed spur, often widening at the top, forms a receptacle from which nectar may be collected; the two-lobed petals; the three-lobed labellum and long gynostemium outgrowths. The labellum consists of narrow elements in all species. It has lost its original function as a landing site which it fulfils in the majority of other orchids as night butterflies do not alight on the flower while seeking sustenance. It would seems that specialization in the manner in which the pollen mass is deposited on an insect's body was a principal factor governing the evolution of species. The long spur ensures that the pollinator, reaching for the nectar inside it with its proboscis, has to push its head, thorax or front legs on to the gynostemium. The lateral outgrowths, equipped with pollinia, touch the insect and enable the pollen to be transferred to its head or front legs. Hence the pollinators of Bilabrella are primarily likely to be butterflies which are active at dusk or during the night (mostly from the Sphingidae and Acherotidae) (van der Cingel 2001).

\section{Identification keys}

While identifying plants from the genus Bilabrella many features which are easily measurable prove use- less because they often depend on habitat conditions and the plants' ecological requirements. Parts of the perianth such as the dorsal or lateral sepals do not enable precise identification of a given specimen to be made as these elements are usually very similar in all Bilabrella spp. When identifying species one should also bear in mind the very frequent existence of abnormal forms which have sometimes been described mistakenly as separate taxa, e.g. Habenaria simense Rchb.f. is a form of Bilabrella antennifea (A. Rich.) Szlach. \& Kras with atypical flowers.

Thus taxonomic classification of specimens should be based on a few fairly stable features. The gynostemium stays pretty constant because, as a generative structure, it is closely related to specific pollinators and determines reproductive success. Its structure is therefore the most important feature in identifying individual taxa within Bilabrella, especially the auriculae, antherophores, rostellophores and stigmaphores. The two petal lobes, spur and mutual relation of the flower pedicel and bract are also highly significant. A vegetative feature that usually characterizes species well is the number and arrangement of the leaves. However, because of interpretation in the gynostemium structure, the keys make use of more easily observable features where possible.

The key for identification of species based on subtle features, often seen under stereomicroscope.

\section{Conclusions}

Bilabrella comprises species easily separable from all other genera of African Habenariinae by the following set of characters: erect, usully slender stem leafy throughout, leaves decreasing in size upwards, manyflowered, elongate inflorescence, deeply bipartite petals, lip divided into 3 lobes, all segments of petals and lip narrow, often linear-lanceolate, prominent spur variously formed, prominent, elongate, narrow projections of rostellum lateral lobes, stigma lateral lobes and anther. The most prognotsic and useful feature in determination of species appears to be those connected with morphology of petals, lip, spur and generative structures.

Species of the genus are known from continental Africa, south to Sahara Desert, Madagascar and neighboring islands, with most of them found in Tropical East Africa. They are heliophytes recorded in open plantcommunities, likes savanna, grassland, and marshes prefering upland and montane areas. 


\section{References}

Bolus H. 1913. Orchids of South Africa 3: tab. 22-24. London, W. Wesley \& Son, Strand.

Brummit R. K. 2001. World Geographical Scheme for Recording Plant Distribution. Ed. 2, pp. 1-152. Pittsburgh, Carnegic Mellon University.

la Croix I. \& CribB P. J. 1995. Orchidaceae. In: G. V. Pope (ed.). Flora Zambesiaca, 11(1): 59-148. Whitstable, Kent, Whitstable Litho Printers Ltd.

van DeR Cingel N. A. 2001. An atlas of Orchid pollination - America, Africa, Asia and Australia. 134 pp. Rotterdam, A. A. Baklema.

GeERINCK D. 1984. Flore d'Afrique Centrale (Zaire-RwandaBurundi), pp. 52-142. Bruxelles, Jardin botanique national de Belgique.

Kraenzlin F. 1891. Beiträge zu einer Monographie der Gattung Habenaria Willd. (Allgemeiner Teil). Botanische Jahrbücher für Systematik, Pflanzengeschichte und Pflanzengeographie 16: 5-41.

KraenZlin F. 1901. Orchidacearum Genera et Species, pp. 174-469. Berlin, Mayer and Meyer.

Kras M. \& SzlachetKo D. L. 2008. Four new species of Bilabrella (Orchidaceae, Habenariinae) from Africa. Polish Botanical Journal 53(2): 97-101.

Kras M. \& SzlachetKo D. L. 2009. Materials to the revision of Habenariinae (Orchidaceae, Orchidoideae). 9. Bilabrella. Richardiana 9(4): 157-160.

LiNDLEY J. 1834. Orchis foliosa. Edwards's Botanical Register 20: sub. t. 1701.

PodBielKowski Z. 1987. Fitogeografia części świata-Europa, Azja, Afryka. 603 pp. Wyd. Nauk. PWN, Warszawa.

ReIchenbach H. G. fil. 1849. Orchidiographische Beiträge. Linnaea 22: 859.

Rendle A. B. 1895. Flora of Eastern Tropical Africa. Journal of the Linnean Society. Botany 30: 393.

Richard A. 1840. Plantes nouvelles d'Abyssinie. Ann. Sci. Nat., Bot. 2(14): 268.

Rolfe R. A. 1913. Flora Capensis, pp. 3-313. London, L. Reeve \& Co.

Schlechter F. R. R. 1906. Orchidaceae africanae. IV. Bot. Jahrb. Syst. 38: 147-149.

Schlechter F. R. R. 1915. Orchidaceae Stolzianae. Bot. Jahrb. Syst. 53: 513-515.

StAfleu F. A. 2011. International Code of Botanical Nomenclature. Regnum Vegetabile 111, pp. 366. New York, Lubrecht \& Cramer Ltd.

Stewart J. \& Campbell B. 1996. Orchids of Kenya, pp. 127143. Winchester, West End House.

Summerhayes V. S. 1931. African Orchids: II. Bulletin of Miscellaneous Informations: 381.

Summerhayes V. S. 1932. African Orchids. IV. Bulletin of Miscellaneous Informations: 341.

Summerhayes V. S. 1942. African Orchids. XII. Botanical Museum Leaflets [Harvard University] 10(9): 257-280.

Summerhayes V. S. 1960. African Orchids. XXVII. Kew Bulletin 14(1): 126-157.

Summerhayes V. S. 1962. African Orchids. XXVIII. Kew Bulletin 16(2): 253-314.
Summerhayes V. S. 1966. African Orchids. XXX. Kew Bulletin 20(2): 165-199.

Summerhayes V. S. 1968. Flora of Tropical East Africa Orchidaceae 1, 236 pp. London, Crown Agents.

Summerhayes V. S. 1968. Flora of West Tropical Africa 3(1), pp. 180-276. London and Tonbridge, The Whitefriars Press Ltd.

SzlachetKo D. L. 1995. Systema Orchidalium. Fragm. Flor. Geobot. Suppl. 3: 1-152.

SzlachetKo D. L. 2003a. Habenariinee (Orchidaceae, Orchidoideae) - Contribution to the Revision of the Subtribe. 3. Die Orchidee 54(2): 82-84.

SzlachetKo D. L. 2003b. Habenariinee (Orchidaceae, Orchidoideae) - Contribution to the Revision of the Subtribe. 3. Die Orchidee 54(2): 85-87.

SzlachetKo D. L. 2003c. Habenariinee (Orchidaceae, Orchidoideae) - Contribution to the Revision of the Subtribe. 6. Die Orchidee 54(3): 70-72.

SzlachetKo D. L. 2003d. Materiaux pour la revision de Habenaria (Orchidaceae, Orchidoideae) - 2. Richardiana 3(4): 153-157.

SzlachetKo D. L. 2004a. Habenariinae (Orchidaceae, Orchidoideae) - Contribution to the revision of the Subtribe. 7. Die Orchidee 55(1): 57-59.

Szlachetкo D. L. 2004b. Habenariinae (Orchidaceae, Orchidoideae) - Contribution to the revision of the Subtribe. 9. Die Orchidee 55(3): 50-51.

Szlachetкo D. L. 2004c. Habenariinae (Orchidaceae, Orchidoideae)-Contribution to the revision of the Subtribe. 10. Die Orchidee 55(4): 91-93.

SzlachetKo D. L. 2004d. Habenariinae (Orchidaceae, Orchidoideae)-Contribution to the revision of the Subtribe. 11. Die Orchidee 55(4): 93-96.

SzlachetKo D. L. 2004e. Materiaux pour la revision des Habenariinae (Orchidaceae, Orchidoideae) - 4. Richardiana 4(2): 52-65.

SzlachetKo D. L. 2004f. Materiaux pour la revion des Habenariinae (Orchidaceae, Orchidoideae) - 5. Richardiana 4(3): 103-108.

SzlachetKo D. L. 2005a. Habenariinae (Orchidaceae, Orchidoideae) - Contribution to the Revision of the Subtribe. 13. Die Orchidee 56(2): 73-75.

Szlachetko D. L. 2005b. Habenariinae (Orchidaceae, Orchidoideae) - Contribution to the Revision of the Subtribe. 14. Die Orchidee 56(3): 65-66.

SzlachetKo D. L., GóRniaK M. \& TukaŁŁo P. 2003. Materiaux pour la revision de Habenaria (Orchidaceae, Orchidoideae) - 3. Richardiana 3(4): 158-162.

SzlachetKo D. L. \& Kras M. 2006a. Notes sur le genre Plantaginorchis (Orchidaceae, Orchidoidae, Habenariinae). Richardiana 6(1): 31-32.

SzlachetKo D. L. \& Kras M. 2006b. Notes sur le genre Habenella. Richardiana 6(1): 33-39.

SzlachetKo D. L. \& Kras M. 2006c. Materiaux pour la revision taxonomique de Habenaria Willdenow (Orchidaceae, Orchidoideae). Richardiana 6(1): 4043. 
SzlachetKo D. L. \& Kras M. 2006d. Materiaux pour la revision des Habenariinae (Orchidaceae, Orchidoideae) -6. Richardiana 6(3): 139-146.

Szlachetko D. L. \& Kras M. 2006e. Materiaux pour la revision des Habenariinae (Orchidaceae, Orchidoideae) - 7. Richardiana 6(4): 178-179.

SzlachetKo D. L. \& Kras M. 2006f. Materiaux pour la revision taxonomique de Habenaria (Orchidaceae, Orchidoideae) - 8. Richardiana 6(4): 196-197.

Szlachetko D. L. \& Kras-ŁapińsKa M. 2003. Habenariinee (Orchidaceae, Orchidoideae) - Contribution to the revision of the Subtribe. 1. Die Orchidee 54(1): 84-87.

SzlachetKo D. L. \& Margońska H. 2004. Habenariinae (Orchidaceae, Orchidoideae) - Contribution to the revision the Subtribe. 8. Die Orchidee 55(2): 40-41.

Szlachetko D. L. \& Olszewski T. 1998. Flore du Cameroun, vol. 34(1), pp. 102-186. Ceper, Yaounde.
Szlachetko D. L. \& Rutkowski P. 2000. Gynostemia Orchidalium I. Acta Bot. Fennica 169: 162-165.

SzlachetKo D. L. \& Sawicka M. 2003a. Habenariinee (Orchidaceae, Orchidoideae) - Contribution to the revision of the Subtribe. 2. Die Orchidee 54(1): 88-90.

SzlachetKo D. L. \& Sawicka M. 2003b. Habenariinee (Orchidaceae, Orchidoideae) - Contribution to the revision of the Subtribe. 5. Die Orchidee 54(3): 67-69.

SzlachetKo D. L., Sawicka M. \& Kras-ŁapińsKa M. 2004. Flora du Gabon, I 36, pp. 28-46. Paris, Museum National d'Historie Naturelle.

The International Plant Name Index - Index Kewensis 2008. Available from: http://www.ipni.org/ipni/ idPlantNameSearch.

Willdenow C. L. 1805. Species Plantarum. Editio quarta 4(1): $5,44$.

Williamson G. 1977. Orchids of South Central Africa, pp. 39-68. London. 